\title{
TRANSBOUNDARY ENVIRONMENTAL GOVERNANCE IN THE EU AND SOUTHEAST ASIA: CONTESTING HYBRIDITY IN THE BIOFUELS AND PALM OIL REGIMES
}

\author{
Helena Varkkey \\ Department of International and Strategic Studies, Faculty of Arts and Social Sciences, \\ University of Malaya, Malaysia \\ helenav@um.edu.my
}

Received: $28^{\text {th }}$ September $2021 /$ Revised: $23^{\text {rd }}$ November $2021 /$

Accepted: $25^{\text {th }}$ November 2021

How to Cite: Varkkey, H. (2021). Transboundary environmental governance in The EU and Southeast Asia: Contesting hybridity in the biofuels and palm oil regimes. Journal of ASEAN Studies, 9(2), 139-158. https:/doi.org/10.21512/jas.v9i2.7757

\begin{abstract}
The research addresses the complexities of the European Union's Renewable Energy Directives (EU RED and RED II), contextualising them within the palm oil sector in Southeast Asia, in which Indonesia and Malaysia are known to be the two largest producers and exporters of palm oil. It aims to question the effect of this expanding role of markets on power dynamics and political processes. Examining these developments at different organisational scales highlights the asymmetrical power relations that circulate through such transboundary networks to shape patterns of resource access and the distribution of environmental risks. Employing a qualitative approach, the research uses case study method to reflect on how market forces and broad political dynamics establish the hybrid environmental governance regime of biofuels. The research concludes that this transboundary market approach to biofuels and palm oil should be regarded with caution, as it (1) lowers regulatory quality within the biofuels sustainability regime, (2) undermines the sustainable palm oil market, and (3) indirectly bolsters unsustainable practices outside the palm oil sector.
\end{abstract}

Keywords: transboundary, environmental governance, palm oil, European Union, Renewable Energy Directives

\section{INTRODUCTION}

Hybridity may undermine sustainable development and environmental justice objectives, and increase economic hardship by leaving too much room for decision-making and 
coercive tactics by powerful private actors (Miller et al., 2020; Stattman et al., 2018). Such hybrid transboundary governance regimes may not be equally well-designed. Environmental conditions may get worse if they produce contradictory directives resulting in operational confusion. Therefore, such regimes should be considered carefully. Miller et al. (2020) argue for the need to understand how such "hybrid governance regimes are being enacted across borders, including in legally flexible ways that span formal and informal spheres, to improve the efficacy and inclusiveness of existing transboundary governance arrangements to sustain transboundary resources and mitigate cross-border environmental threats and crises". An example of a transboundary complex environmental issue extending beyond jurisdictions is the global market for biofuels.

Miller et al. (2020) have argued for the potentially productive role of markets in mitigating such ecological issues. Accordingly, various states developed national (and in the case of the EU, regional) regulations, subsidy systems, and directives to uphold production, trade, and use of biofuels against standardised sustainability requirements. This came alongside the development of national and transnational private and multi-stakeholder sustainability certification schemes, both directly and indirectly focused on biofuel sustainability. Such elements characterise the hybrid transnational governance of sustainable biofuels: 1) institutionally co-existing alongside intergovernmental regimes and complex overlaps and 2) interactions between national and transnational elements (Ponte \& Daugbjerg, 2015).

The application of state authority to such private certification schemes, like in the case of the European Union Regional Energy Directive (EU RED), has been assumed to "harden" accountability towards more sustainable production. As the state can set legally binding requirements, this is expected to be able to coerce corporate entities into submission (Moser \& Leipold, 2019). However, Kemper and Partzch (2018), Larsen et al. (2014), Moser and Leipold (2019), and Stattman et al. (2018) have argued that "instead of yielding an increasingly stringent sustainability framework, the hybrid EU governance arrangements resulted in a proliferation of relatively lax, industry-driven sustainability standards". Hence, there is still an ongoing debate in the literature about whether a hybrid approach can strengthen or weaken sustainability objectives (Stattman et al., 2018).

\section{METHODS}

The research centres the academic debate around the EU RED in Southeast Asia, where Indonesia and Malaysia are the largest producers and exporters of palm oil, a type of biofuel. Considering the latest developments under EU RED II and responses from both countries, the research takes a qualitative approach and uses the case study method to reflect on how market forces and broad political dynamics can shape the hybrid environmental governance regime of biofuels. The research employs the researcher's own knowledge and understanding of the selected case study combined with an extensive review of the academic literature on both the biofuels and palm oil sustainability regimes. Furthermore, it also provides detailed content analysis of recent official documents and statements from major stakeholders to reflect on the sustainability outcomes of transboundary market approach to biofuels and palm oil. Miller et 
al. (2020) point out that "understanding hybrid environmental governance through this fluid register of (market and political) power relations afford heightened visibility of the differentiated beneficiaries of environmental benefits" within such regimes.

The research follows Miller et al. (2020) who argue that the market's considerable role in environmental governance can be seen as less about economic activities and more about power dynamics and political processes. Miller et al. (2020) consider how "power relations circulate through transboundary geographies of hybrid governance to allow or block access to the benefits of particular resources, resulting in (redistributive) inclusions and exclusions, with implications for environmental (in)justice". They argue that both state and private actors engage transboundary networks at the national and translational scales to increase their respective power positions and ecological agendas. Through such processes, hybrid environmental governance regimes become sites of political contestation. Powerful states may attempt to design and broker arrangements that reinforce unequal power relations to maintain their hegemonic values in lieu of actual ecological reforms, while weaker actors may try to mobilise to resist attempts at enclosure and resource capture by more powerful states.

The research offers a conceptual discussion of transboundary environmental governance and locates hybrid forms of the same within the literature. It is followed by elaboration on the market-based sustainable governance regimes of both biofuels (in the EU) and palm oil (based in Southeast Asia). The research then describes the interplay of these hybrid instruments as sites of political contestation, focusing on how power dynamics have influenced outcomes within these regimes. Finally, it discusses how these market, political, and power dynamics affect sustainability trajectories within both of these sectors and regions.

\section{RESULTS AND DISCUSSIONS}

\section{Hybrid Forms of Transboundary Environmental Governance}

The United Nations Development Programme (UNDP) (in Haque, 2018) defines governance as "the exercise of one's political, economic, and administrative powers or authorities at various levels". This includes procedural and institutional mechanisms that actors can use to actualise their rights and interests, fulfil obligations, and negotiate differences. Badenoch (2001) defines environmental governance as encompassing the range of "processes and structures that underlie the decision-making processes that affect the environment, however unintentionally". An environmental view of governance thus includes examining the "rules of the game" and "who gets to play" in ecological issues and encompasses more than just the environmental sector. Thus it refers to how the debate is held, decisions are made, and authority is exercised over the environment (Woods, 2003).

Traditional types of state-led environmental governance have often been inadequate to solve transboundary environmental problems. Such complex environmental problems often extend beyond individual property regimes and jurisdictions, and generate cascading and farreaching impacts such as market fluctuations, livelihood transformations and human displacement and resettlement. They cannot be resolved at a single scale of decision making 
within the boundaries of administrations or individual countries (Miller et al., 2020). For example, in Southeast Asia, ASEAN member states agree to adopt a collective approach to regional transboundary haze governance after national efforts proved inadequate to address this complex air pollution problem involving transnational capital, state-to-state relations, and global commodity markets (Varkkey, 2016). In the scope of marine pollution management, the Mediterranean Action Plan materialised due to the inability of Mediterranean states to adequately govern the movement of marine pollution across borders in the Mediterranean basin, which negatively affects environmental health and tourism in the region (Thacher, 1977). Formal state-level institutional structures, especially in the developing world, tend to have weak implementation which limits environmental governance effectiveness (Larsen et al., 2014). Badenoch (2001) offers transboundary environmental governance as an alternative approach, which involves "the interaction of many actors along two axes: vertically through the various levels of government administration and inter-governmental cooperation, and horizontally among the range of state-market-community actors".

Transboundary environmental governance can mean many things, among them "private" and "non-state, market-driven" transnational governance (Ponte \& Daugbjerg, 2015). However, while scholars have acknowledged the shift of such state to non-state types of authority, there is also an understanding that this has not weakened the state. Such a condition is known as hybrid governance defined by Ponte and Daugbjerg (2015) as "a form of governance where public and private come together in complex configurations that include civil society, business, and a plethora of nontraditional actors". Hence, hybrid means more than a varied combination of public and private governance components. It denotes their "mutual dependence and deep interrelation, characterised by polyarchic and overlapping governance arenas, where interactions between a variety of mutually dependent private and public actors give rise to hybrid regulatory features, and where collective orders and individuals engage in cross-border rulemaking, implementation, and enforcement activities" (Ponte \& Daugbjerg, 2015). Miller et al. (2020) have further refined this definition as "deliberative, multisector (cogovernance, public-private, and private-societal) partnerships that collaboratively produce, synthesise, and mobilise knowledge from diverse sources and through flexible institutional arrangements".

Such hybrid models serve as an appealing alternative to the often piecemeal and inflexible traditional forms of environmental governance. Some scholars have argued that hybrid governance should increase the capacity of governments to fulfil sustainability objectives, including environmental protection, social advancement, and economic prosperity. This is mainly linked to the belief that state-led initiatives that include private governance efforts will technically promote stricter criteria and best practices towards a race to the top (Stattman et al., 2018).

However, when competition is created between private schemes due to multiple governance options, the resulting fragmentation can weaken sustainability through a race to the bottom (Stattman et al., 2018). Miller et al. (2020) point out that hybrid governance regimes furthermore tend to validate "democratic environmental collaborations, usually with the support of market incentives, without fully understanding the trajectories of different 
combinations of hybrid regimes or their interplay at specific scales of governance". Hence, such hybrid intervention can produce suboptimal environmental outcomes if major stakeholders cannot resolve coordination issues, adapt to change, overcome trust issues, or confront power asymmetries. Furthermore, failing to systematically organise and exchange information needed for transboundary decision making can undermine such hybrid arrangements right from the planning stage. This process is rarely straightforward or smooth, involving coordination across often contrasting political dynamics and ideologies (Miller et al., 2020). Therefore, perceiving the political dynamics of hybrid environmental governance arrangements is vital in understanding the complex and contradictory development in environmental governance.

\section{Creating A Market for Sustainable Biofuels in the EU}

While biofuels have been put forward as a viable alternative to fossil fuels, doubts have been cast on the impact of biofuel production on greenhouse gas (GHG) emission reductions. Biofuels have been blamed for causing serious food price increases as it removes water and land from food production. Further climate justice issues include inequitable land investments, limited local benefits and participation in decision-making, and ecological degradation (Ponte \& Daugbjerg, 2015; Pye, 2010).

Transnational governance focusing on markets can be potentially productive in addressing sustainability issues (Miller et al., 2020). Larsen et al. (2014) argue that incorporating sustainability standards into government regulations in importer countries and regions can improve the accountability of market actors. In the context of biofuels, they argue that voluntary multi-stakeholder sustainability standards can complement weaker public regimes and, by extension, improve accountability in international markets of biofuel products. However, this must be couched against existing hybrid sustainability regimes and market incentives for palm oil, a major type of biofuel. Hence, it is important to understand the trajectories of both the EU biofuel regime and the Southeast Asia-based palm oil regime and their interplay at specific scales of governance.

The EU biofuels governance regime has succeeded in creating an important market for biofuels (Oosterveer, 2020) and stimulating global demands for vegetable oil (Larsen et al., 2014). Indeed, without the policy, there would be no market for feedstock-based biofuels in the EU (Oosterveer, 2020). The EU started to develop its own biofuels policy in 2001 (Wahid, 2008). The first EU biofuels directive entered into force in 2003 to promote biofuels and other renewable fuels for transport. It set a voluntary blending target of $2 \%$ renewable energy in the transport sector in 2005 and a binding target of 5,75\% in 2010 .

It resulted in a growth in imported sugarcane bioethanol from Brazil and soybean biodiesel from the United States due to lower production costs (Stattman et al., 2018). Imports of palm oil from Southeast Asia also continued growing to serve the new biofuel market (Oosterveer, 2020). While the EU officially reported a GHG emissions savings of $14.0 \mathrm{Mt}$ in 2007, lobbyists, environmental organisations, and scientists began positing that the EU-driven increase in international trade of biofuels led to increased emissions overseas due to indirect 
land-use change (ILUC) there. The much-discussed link between palm oil and deforestation at the time quickly spotlighted land-use change in palm oil-producing countries as a primary concern. The 2007-2008 food price crisis also raised concerns that biofuels were taking land and water away from food crops, and thus driving food prices up. It was proposed that these indirect adverse effects should be considered risks to be mitigated in EU biofuels policies (Stattman et al., 2018).

In response to this, the EU came up with a follow-up directive, the EU RED, in 2009. The EU RED required that at least $20 \%$ of the EU's total energy needs should come from renewables by 2020 , of which at least $10 \%$ should come from renewable transportation fuels. To qualify, biofuels should meet these sustainability criteria: (1) It should achieve GHG savings of at least 35\% compared to fossil fuels; (2) It cannot be cultivated on previously high carbon stock land like wetlands or forests; and (3) It cannot be produced from raw materials obtained from high biodiversity land like primary forests or high biodiversity grasslands (Stattman et al., 2018).

In this way, the EU set a "meta-standard" (basic, minimum sustainability requirements) for biofuels which could be counted towards national renewable energy targets (Ponte \& Daugbjerg, 2015). However, the World Trade Organization (WTO) regulations limited the ability of states to impose product requirements and regulations on other members (Stattman et al., 2018). Furthermore, imported biofuels' sustainability criteria are based on productionlevel attributes, with production centres often located outside the EU. Therefore, Ponte and Djauberg (2015) argue that the EU "needed private certification schemes to extend its authority and capacity to implement the environmental sustainability criteria beyond its territorial borders". Many private certification schemes were created in response to this demand, leaning on the RED incentives to establish themselves as a legitimate market-based instrument for sustainability governance. Some schemes are limited to a specific national scope, while others could potentially be applicable worldwide. Some cover specific crops or specific parts of the production chain, while others cover all crops and the whole production chain. Seven private schemes were first accepted (on five-year terms) by the EU in 2011, which increased to 19 in 2016 (Stattman et al., 2018).

However, the EU RED criteria continued to be challenged, especially on the absence in the policy of GHG impacts from ILUC caused by biofuel feedstock production and social impacts, including consequences for food security. However, palm oil imports for biofuel continued to grow and replaced soybean oil as the most imported biofuel feedstock by 2015 (Oosterveer, 2020). In response to citizen concerns over palm oil, the EU RED II was introduced as an updated policy framework for 2021-2030. Under this iteration, the target for agricultural feedstock-based biofuels was reduced to $7 \%$ from $10 \%$, so countries could introduce tax incentives and quota measures to achieve this. Some existing sustainability measures were tightened, such as an increase in the requirements for GHG savings from $35 \%$ to $65 \%$, with palm oil clocking in at only $45 \%$ of savings (Oosterveer, 2020).

Thus, EU RED and RED II have increasingly complex transnational and hybrid features (Ponte \& Daugbjerg, 2015), with the hybridity of the system being based on deep public-private 
interdependence and interconnection (Pacheco et al., 2020). This integration of private initiatives created a hybrid biofuel governance landscape consisting of public standards and private certification initiatives to govern access to the EU biofuels market (Stattman et al., 2018). At the same time, and evolving quite independently from the EU biofuels regime, a complex governance regime for palm oil, which has in recent years replaced soybean oil as the main imported feedstock for biodiesel into the EU, has developed in response to its own unique sustainability issues (Pacheco et al., 2020).

\section{Parallels with the Palm Oil Sustainability Regime}

Due to its production efficiency, low price point, and usage versatility, palm oil has become the world's leading vegetable oil, representing more than $35 \%$ of the global vegetable oil market. It is also a highly tradeable commodity, with around $70 \%$ of its production traded internationally. India is currently the largest importer of palm oil, followed by the EU and China. In the EU, palm oil is becoming an increasingly important input in the processing and food industries in Europe (Oosterveer, 2020). However, the expansion of oil palm, especially when on peatlands, produces significant amounts of emissions and drives biodiversity loss when on primary forests (Pacheco et al., 2020). Consumer concerns over these sustainability issues, particularly in Europe and North America, have resulted in bad publicity for the commodity and inspired boycotts against producers using palm oil (Oosterveer, 2020). To address these sustainability issues, various state and non-state regulatory initiatives have been developed, resulting in regime complexity characterised by "parallel or overlapping and competing initiatives [that] are not combined into a single hierarchical system" (Overdevest \& Zeitlin, 2012 in Pacheco et al., 2020).

The Roundtable for Sustainable Palm Oil (RSPO) is the most widely adopted private standard within the palm oil sustainability regime. RSPO was set up in 2004 which involves third-party compliance monitoring of adherence to the RSPO standard, primarily addressing palm oil-specific land and environmental performance issues (Pacheco et al., 2020). Several loose coalitions, including the Palm Oil Innovation Group (POIG - NGOs and corporations) and the Indonesian Palm Oil Pledge (IPOP - Indonesia's "big five producers), pushed for

additional standards related to deforestation, planting on peat, and social exploitation ("No Deforestation, No Peat, No Exploitation" or NDPE) beyond RSPO's existing standards. Responding to this, an enhanced voluntary standard, termed "RSPO NEXT", was introduced in 2015, incorporating NDPE norms (Nesadurai, 2018). RSPO has also developed the shortlived RSPO-RED, which attempts to comply with the EU RED sustainability criteria (Stattman et al., 2018),

As the largest and second-largest palm oil producers worldwide, respectively, the Indonesian and Malaysian governments also have developed their own certification schemes. The Indonesian Sustainable Palm Oil (ISPO) mandatory certification scheme was launched in 2011, and the Malaysian Sustainable Palm Oil (MSPO) was launched as a voluntary scheme in 2014, which became mandatory in 2017. Unlike RSPO, which relies on voluntary participation, ISPO and MSPO rely on national government regulations (Oosterveer, 2020). Furthermore, 
while all these schemes claim to be sustainable, they all differ slightly in their principles in criteria, reflecting the malleability of this concept (Lélé, 1991). The MSPO and ISPO have applied to be recognised under the EU RED criteria but failed. While the creation of the EU biofuel regime has indeed created an expanded role for markets in biofuel sustainability governance. The research provides elaboration that this must be understood as less about economic activities and more about power dynamics and political processes.

\section{The EU as a Normative Environmental Power?}

The EU is considered a powerful and influential actor due to its wealth, political competencies, legal personality, and power to bind members, which feed into its ability to exert leverage and develop complex policy (Vogler \& Stephan, 2007). It is also recognised as a considerable 'normative power', first described by Manners (2002, in Afionis \& Stringer, 2012) as "a distinct actor that is guided by and seeks to advance in the wider world the values and ideas on which it is founded upon, including democracy, the role of law, human rights and fundamental freedoms". Sustainable development was explicitly identified as a fundamental objective of the EU's relations with the outside world in its 1997 Amsterdam Treaty and successors. It has become a core norm within the EU's normative outlook, which it promotes through enlargement, environmental, trade, foreign and development policies (Afionis \& Stringer, 2012).

The EU has been recognised as a normative international leader of sustainable development at least since the late 1980s. It played significant roles in promoting the 1989 Basel Convention on hazardous waste, strengthening the 1989 Montreal Protocol, providing leadership during the 1992 Rio Conference, creating the 1995 Intergovernmental Panel on Forests, supporting the 2000 Cartagena Protocol on Biosafety, influencing the 2001 Stockholm Convention on Persistent Organic Pollution, developing the UN Framework Convention on Climate Change (most significantly through the 2005 Kyoto Protocol), and 'greening' the WTO (Afionis \& Stringer, 2012; Bretherton \& Vogler, 2000; Delreux, 2009; Vogler \& Stephan, 2007). It chose to use its platform at the 2002 Johannesburg Summit to communicate its 'Europe 2020 Strategy' for smart, sustainable, and inclusive growth. It pushes to keep sustainable development on the agenda of important international organisations and processes such as the G8, G20, World Bank, UN Security Council and General Assembly, and the World Health Organization (Afionis \& Stringer, 2012). Promoting a global sustainability agenda in these manners has been seen as evidence of the EU genuinely attempting to fulfil its normative role successfully and credibly. On these grounds, it could be understood that the EU's normative leadership departs from the realpolitik tradition by promoting the global common good, arguably over and above the national interest (Falkner, 2007 in Afionis \& Stringer, 2012).

However, the concept of sustainable development is highly malleable (Lélé, 1991), and scholars have noted how the EU upholds its normative environmental leadership position based on its own narrow interpretations of the concept even while it pursues unsustainable trade strategies (Afionis \& Stringer, 2012; Bretherton \& Vogler, 2000). Cracks became visible in 
this façade when the EU played an active role in inserting text into the UNCED's Agenda 21, but without insisting on the inclusion of trade, an issue area where it would have had a substantial influence based on the size of its single market (Vogler \& Stephan, 2007). Following this, several notable cases have highlighted the divergences between the EU's trade interests and its environmental policies, including the EU's refusal to ban the import of furs from important trading countries obtained through inhumane methods and its refusal to take a stance on Genetically Modified Organisms for fear of souring transatlantic trade relations (Bretherton \& Vogler, 2000).

By viewing EU's normative environmental leadership through a political economy lens, it can be argued that economic and trade interests are the key motivators for EU's leadership in international ecological policymaking, while normative aspirations maintain a subsidiary role (Kelemen, 2020 in Afionis \& Stringer, 2012). While Vogler and Stephan (2007) argue that "there is no necessary contradiction between the promotion of European values, the pursuit of economic interests, and the strong support for a more ambitious agenda of global regulation", the research argues that the EU's position as a normative environmental power augments its own power position and sustains its own hegemonic values vis-à-vis other countries. In this manner, the research argues that the EU biofuels governance regime has become a site of political contestation.

\section{Political Economy of EU Biofuel Governance}

The rapid development of the EU biofuels policy can be linked to both a normative concern for the environment and realpolitik considerations. Before the biofuels policy, the EU's transport system was almost completely reliant on oil from Russia and the politically unstable Middle East and Central. Furthermore, the EU was not on track to meet its Kyoto Protocol emissions reduction targets (Afionis \& Stringer, 2012). Under the Kyoto Protocol, the EU committed to an $8 \%$ GHG reduction by 2012 and 20\% by 2020 (Kemper \& Partzsch, 2018). Failure to achieve these targets would deliver a major blow to the EU's position as a global environmental leader (Afionis \& Stringer, 2012). Therefore, taking advantage of the malleability of the concept of sustainable development, the EU focused its biofuels sustainability criteria on GHG reductions to effectively contribute to its commitments under the UN Framework Convention on Climate Change (UNFCCC). This pragmatic determination of sustainability criteria to fulfil international commitments has ignored other equally important aspects of sustainability. For example, Kemper and Partzsch (2018) and Larsen et al. (2014) determine that the EU RED standards does not promote water sustainability at production sites on the ground.

A major criterion to the EU RED was that biofuels may only be counted towards the $10 \%$ renewable transport fuels requirement if they achieved GHG savings of at least $35 \%$ over fossil fuels. There is, however, no specific scientific consensus pointing towards the necessity of this figure. Rather, it conveniently ensures that the heavily subsidised domestic rapeseed oil will qualify by a small margin, but the default GHG savings of palm oil and soybean biodiesel would not (Erixon \& Abbott, 2009; Meredity, 2012). This attempt to limit future market 
expansion for the EU's main biofuel competitors fulfils the demands of local vegetable oil producers arguing that their products should be preferred over imported vegetable oils (Firrisa et al., 2014 in Oosterveer, 2020) and connecting to the EU's earlier geopolitical concerns of reducing the dependence of imported sources of energy. The EU works through the transboundary network to augment its own power position and interests (Miller et al., 2020).

Positioned as a powerful global actor in more ways than one, it is implicitly understood that when the EU adopts a standard, other countries will adopt similar standards or comply with the EU standard in other ways to prevent being locked out of the EU market. Hence, the EU can use its market power to incentivise other countries to behave in an acceptable manner according to the EU's view (Erixon \& Abbott, 2009). Hence, several certification schemes were quickly established and modified in the attempt to be recognised under EU RED to gain market access. One example is the German-based International Sustainability and Carbon Certification (ISCC), established in 2010 specifically to certify biofuel feedstock, including crude palm oil (CPO) for the EU biodiesel market (Pacheco et al., 2020), and was among the first set of schemes recognised by the EU RED in 2010. RSPO, certifying a large chunk of the Southeast Asian market, introduces RSPO-RED, a voluntary add-on to the generic RSPO Standards and Criteria. RSPO-RED used methane capture to meet the 35\% GHG reduction requirement. In November 2012, RSPO-RED was accredited under EU RED. The accreditation expired in 2016 (Stattman et al., 2018) and was renewed in 2019 until 2021. However, the EU indicated that the scheme would not be renewed after 2021 as the scheme did not adhere to the EU's narrow interpretations of biofuel sustainability.

This was followed by another European Parliament decision in 2018 to phase out palm oil as a feedstock for biofuels by 2021 (Stattman et al., 2018). However, explicitly excluding palm oil would raise legality issues as it would not comply with WTO requirements (Oosterveer, 2020). Therefore, a slightly softened version of the EU RED II went ahead at the end of 2018. In this iteration, a distinction was made between high-risk and low-risk ILUC biofuels. High-risk biofuels were defined as those produced from a feedstock for which there has been observed a significant expansion of the production area into land with high carbon stock. These types of biofuels would need to peak at 2019 levels and be phased out by 2030 unless specific batches could be certified as low-risk. In the operationalisation of this criterion, the expansion into high carbon forest for palm oil was calculated as $45 \%$, and $9 \%$ for soybean. Under these calculations, even though palm oil was not specifically identified, it was almost automatically considered a high-risk ILUC biofuel feedstock (Oosterveer, 2020). This would render palm oil "virtually unmarketable" within the EU member states as palm oil would be more expensive than both fossil fuels and domestically produced biofuels without the RED tax benefit (Meredity, 2012).

Hence, by erecting barriers aimed at shielding its own inefficient domestic biofuels production, the EU is placing trade competitiveness and economic growth above normative environmental protection, thus permitting sustainability concerns to be addressed only in part. The EU's selective interpretation of sustainable development has not compelled EU-based actors to radically change existing developmental practices while forcing external actors to adapt to their own narrow interpretation of sustainability. It is indeed ironic that a powerful 
normative actor, so keen on promoting environmental sustainability, is so openly impeding palm oil imports based on its own questionable and limited sustainability criteria. Palm oil is not only more energy-efficient than its heavily subsidised domestic counterparts (Afionis \& Stringer, 2012) but also has a robust sustainability regime of its own. Despite this, the EU, leveraging upon its normative and market power, brokered a settlement designed to reinforce unequal power relations between itself and palm oil-producing states that sustain narrowly defined 'European' sustainability values and assign benefits to local agro-industry at the expense of genuine environmental reforms (Oosterveer, 2020).

\section{Market-Based Resistance and Cooperation Among Producer States}

The outcomes of these arrangements effectively attempt to block access of less powerful states (palm oil producers) to the benefits of trade with the EU, with implications for environmental and trade (in)justice which has been described as "green protectionism" Afionis and Stringer (2012), Arief et al. (2020), Erixon \& Abbott (2009), Meredity (2012), and Ponte and Daugbjerg (2015). In response to such developments, weaker states will often try to mobilise to resist resource capture and enclosure by these more powerful actors (Miller et al., 2020). Indeed, the two main palm oil-producing states, Indonesia and Malaysia, have tried to mobilise to resist the market-limiting efforts at the EU, primarily through collaborative, market-based mechanisms.

Palm oil and biofuels aside, the Southeast Asian, or ASEAN, region remains an important trading partner for the EU (Mazur, 2017). European exporters have tried to increase access to Southeast Asian markets through EU trade agreements (Meredity, 2012). The EU kick-started negotiations with ASEAN towards a region-to-region Free Trade Agreement (FTA) in 2006. While 2010 saw the redirection of negotiations to state-to-regional (EU) FTAs, the EU reaffirmed that its ultimate objective was to reach an agreement with ASEAN (Mazur, 2017). Soon after, Singapore and Vietnam concluded bilateral FTAs with the EU (Tham, 2012). However, bilateral negotiations with Malaysia and Indonesia are still ongoing. Both countries have expressed that continued barriers to palm oil trade vis-à-vis the EU RED II would be a "deal-breaker" for these bilateral FTAs (Lim, 2018; Tham, 2012). In context, palm oil only contributes $4,4 \%$ of the total EU-Malaysia trade, where only $1,4 \%$ of it is used for biofuels that fall under RED II limits (Varkkey, 2020). However, the national interest significance of the sector (Choiruzzad, 2019), and the perceived power dynamics at stake, has put Malaysia and Indonesia in a position willing to sacrifice these FTAs despite complementarities and benefits in other trade areas. Furthermore, given the centrality of both these states in ASEAN, this may also have further regional effects on the planned ASEAN-EU agreement, as has been explicitly expressed by Malaysia (Varkkey, 2020).

Indonesia has also submitted an official request for a consultation with the WTO Dispute Settlement Body (DSB) over "certain measures concerning palm oil and oil palm cropbased biofuels" under the EU RED II ("European Union", 2019). After an initial block, Indonesia's second request was approved by the DSB for a panel to examine certain measures adopted by the European Union and EU member states affecting palm oil and oil palm crop- 
based biofuels. Malaysia has reserved its rights to participate in the proceedings as a third party as a 'sign of solidarity and support' alongside other palm oil producer countries Thailand, Guatemala, Costa Rica and Colombia, and major agricultural exporters the United States, Canada, Brazil, and Argentina ("Panels established to review", 2020). Third parties receive the parties' first written submissions to the panel and present their views orally to the panel during the first substantive meeting. Malaysia has also submitted its official request for WTO consultation in early 2021, which has also been accepted ("European Union and certain member", 2021).

Both countries have argued that the EU RED II violates the principle of nondiscrimination in the WTO (Arief et al., 2020) and has the potential to damage the reputation of palm oil in non-biofuel EU markets (Siahaan, 2020). The WTO's basic free trade tenets are understood such that if a foreign product looks like a domestic product, it should not be taxed or sanctioned differently from that domestic product. As rapeseed oil and palm oil are virtually identical in terms of functions and physical characteristics, Erixon \& Abbott (2009) and Meredity (2012) have predicted that the WTO will likely demand a repeal of the policy to allow Southeast Asian palm oil to compete freely in Europe, using existing certification schemes like the RSPO, ISPO, and MSPO. With the EU already being on the losing end of at least two biodiesel-related cases that it brought to the WTO in 2013 (anti-dumping of soybean-based biodiesel from Argentina and palm-oil based biodiesel from Indonesia), further losses should deliver considerable blows to EU's global normative standing (Oosterveer, 2020).

These responses were coordinated through the Council of Palm Oil Producing Countries (CPOPC). The CPOPC was found by Indonesia and Malaysia in 2015 originally to harmonise the Indonesian ISPO and Malaysian MSPO sustainability standards (Nesadurai, 2018), but has now developed to become a platform to coordinate palm oil diplomacy and trade access efforts of the commodity's largest producers (Siahaan, 2020) (Colombia, the thirdlargest producer pf palm oil, has recently joined). For example, the CPOPC made a strong statement against the EU RED II at the ASEAN-European Union Summit in 2017, where FTAs were discussed (Wibowo \& Ratnawati, 2020). Other coordinated efforts include Indonesia's ban of products labelled as 'palm oil-free' and the Malaysian government's implicit support of retailers doing the same (Australian Industry Group, 2019).

The CPOPC's Ministerial Meeting in 2019 called for unity among palm oil-producing countries in combating discriminatory trade measures against palm oil through aggressive joint campaigns (Siahaan, 2020). Its eighth meeting in 2021 continued in this vein, with discussions focusing on bolstering cooperation between Indonesia and Malaysia over palm oil. Possibly in response to the contested science and calculations on GHG emissions related to palm oil under the EU RED, the CPOPC established a Scientific Committee to focus on research and development activities for the enrichment of public knowledge on palm oil commodity ("Indonesia, Malaysia to bolster", 2021). In addition to Colombia, representatives from Ghana, Honduras, and New Guinea attended the meeting as observers.

The collaborative approach is interesting, considering that Indonesia and Malaysia avoid bilateral cooperation over palm oil for decades, with both marketing their own palm oil 
as superior to the other (Varkkey, 2016). However, when confronted with the EU using and augmenting its position of power and influence in the interest of its own agro-industry, these two weaker producing countries decided to mobilise (sometimes together with other smaller producer states) to resist such resource capture and enclosure jointly. While joint diplomatic efforts (like the CPOPC Joint Mission to Brussels in April 2019 to appeal against the EU RED II) (Wibowo \& Ratnawati, 2020) may be less effective due to the large power differentials between the two parties. The market-based mechanisms may speak more directly to underlying economic and trade interests of the EU.

The EU's response, suggesting that EU RED II fulfilled WTO regulations by establishing sustainability criteria for biofuels that are global, objective, and nondiscriminatory to meet the EU's renewable energy targets and not limit access to the EU biofuels market (Arief et al., 2020), would seem to be once again leveraging upon its position as a global normative leader to justify its policy choices. However, the recent establishment of the EU and ASEAN Joint Working Group on Palm Oil and its first meeting held in early 2021 significantly marks a possible 'softening' of the EU's stance in the face of mobilisation and resistance (Roozen, 2021).

\section{Hybrid Governance and Sustainability Trajectories}

By focusing on the same crop, the interplay between the EU RED II biofuel governance regime and the Southeast Asia-based palm oil sustainability regime has resulted in a complex hybrid environmental governance regime with effects across governance scales, trading markets, and political actors. It has been warned that such hybridity and fragmentation can result in operational confusion among regulators, economic providers (producers and manufacturers), civil society observers, and consumers (Larsen et al., 2014; Miller et al., 2020; Pacheco et al., 2020; Stattman et al., 2018; von Geibler, 2013). What follows would be suboptimal outcomes for sustainable development and environmental justice (Miller et al., 2020; Stattman et al., 2018). Such suboptimal hybridity within the biofuels and palm oil regime can be observed in at least three distinct ways: (1) the lowering of regulatory quality within the biofuels sustainability regime, (2) the undermining of the sustainable palm oil market, and (3) the indirect bolstering of unsustainable practices outside the palm oil sector.

Firstly, both European biofuels and the Southeast-Asian based palm oil sustainability regimes, and the schemes within them, vary widely in the scope of their standards, modes of implementation, and compliance costs (Larsen et al., 2014), reflecting the malleability of the concept of sustainability. The resulting fragmentation can decrease sustainability through a race to the bottom when there is competition between schemes due to various governance options (Stattman et al., 2018). In the case of biofuels, the EU considers schemes initiated and developed both before and after the RED. RSPO was developed before the EU RED to address sustainability issues within the whole palm oil sector, not just for biofuels to Europe. Such roundtable-based programs tend to stipulate more stringent environmental and social sustainability criteria. Indeed, the sustainability requirements under RSPO already went beyond the requirements of the EU RED (Larsen et al., 2014). However, these additional 
features were of no interest to the EU (Larsen et al., 2014), which was only interested in the strict (and arguably arbitrary) (Sharman \& Holmes, 2010) criteria under RED.

On the other hand, programs created (or, in the case of ISCC, fully fleshed out) after RED were explicitly designed to serve as certifiers for the European biofuels market. They tend to be business-led, which include RED-stipulated sustainability criteria only and discriminate more easily against the global South. Due to the less rigid and more affordable production rules and auditing standards, these types of standards tend to dominate (Kemper \& Partzsch, 2018; Moser \& Leipold, 2019; Pacheco et al., 2020; Ponte \& Daugbjerg, 2015). Indeed, the European-based ISCC is considered relatively more accessible, as it is leaner, quicker, and more in tune with industry interests (Ponte \& Daugbjerg, 2015). This has paid off with most biofuel feedstock including palm oil biofuel, which enters into the EU market is currently certified under the ISCC scheme (Oosterveer, 2020), with $85 \%$ of companies certified under RED having ISCC certification in 2017 (Moser \& Leipold, 2019). In comparison, despite RSPO's RSPO-RED scheme, which was specially designed to align with RED, "no [RSPORED certified] tonnes were shipped [since its recognition in 2012], and currently there are no RSPO-RED certified growers [due to lack of demand]". RSPO has since decided to discontinue the scheme upon its expiry in 2021 ("RSPO-RED scheme not to be", 2020). Such race-to-thebottom outcomes lower the overall regulatory quality of the regime and discourage the expansion of a more inclusive, sustainable, and transparent certification system for biofuels in Europe (Ponte \& Daugbjerg, 2015).

Secondly, the EU RED II regime has also indirectly undermined the efforts in the palm oil sustainability regime and the palm oil sustainability market more broadly. For example, in 2017, a European Parliament resolution questioned the "ecological and social integrity" of certification schemes like the RSPO, MSPO, and ISPO, and thus their value as benchmarks for sustainable palm oil (Nesadurai, 2018), which reflects the perceived lesser credibility of these schemes among European constituencies (Nesadurai, 2018). This is despite recognition elsewhere: 1) Scholars and commentators have acknowledged that the RSPO performs better on many sustainability criteria compared to ISCC (Nesadurai, 2018; Stattman et al., 2018); and 2) MSPO has received recognition from bodies such as the Tokyo 2020 Olympics and Paralympics Games Sustainable Sourcing Code Committee, China's Green Food Development Centre, and the Solvent Extractors' Association of India (Sani, 2020). This is especially ironic since a major driver for developing these schemes was the sustainability demands of Western consumer goods manufacturers, NGOs, and governments (Siahaan, 2020; Nesadurai, 2018; Pichler, 2013). The market for certified sustainable palm oil (CSPO) remains limited as downstream corporate buyers, mainly in Europe, did not match their pledges with the actual purchase of CSPO. For example, uptake of RSPO-certified CSPO has been less than $50 \%$, keeping premiums low (Nesadurai, 2018). This has translated to only around $20 \%$ of palm oil produced globally being RSPO-certified even though $40 \%$ of total palm oil is produced by RSPO members (Nesadurai, 2018).

Such lacklustre demands reduce the incentive for these schemes to strengthen their standards continually. For example, both MSPO and ISPO continue to suffer from unresolved issues like tenure rights and the conservation of high-carbon forests within concessions 
(Pacheco et al., 2020) and RSPO's challenge remains in smallholder inclusion. It also reduces grower interest to comply with difficult sustainability certifications (Nesadurai, 2018). In addition, it encourages the sector to make strategic market adjustments by refocusing export to equally lucrative but less demanding (by way of sustainability) markets like India, Pakistan, and China and utilising similarly less demanding domestic markets (Rifin et al., 2020). Indeed, exports to these countries have been steadily growing (Erixon \& Abbott, 2009; Nesadurai, 2018; Pacheco et al., 2020; von Geibler, 2013), and both Indonesia and Malaysia have been actively strengthening their national biofuels policies as key strategies to increase domestic palm oil consumption (Varkkey, 2020; Varkkey, 2018).

Thirdly, the EU RED II guarantees that the market demand for biofuels remains regardless of palm oil supply to the region. The narrowing of the European market for palm oil would mean that this demand would have to be filled by less land-efficient and energy-efficient oils. Palm oil uses the least amount of land area (also less fertiliser and pesticide) than other key crops like soybean, sunflower, and rapeseed. Thus, it is the most land-efficient oilseed crop, producing around nine times the yield per hectare of competing oils (Nesadurai, 2018). Schubert et al. (2010 in Meredity, 2012) have explained that "to the extent that demand remains for the food or feed previously produced on [the] land [in question], its production is likely to shift elsewhere". Hence, the shift away from palm oil may drive even larger deforestation rates elsewhere (for example, soybean in Latin America), as even large areas of land will be needed to produce these less land-efficient oils. Currently, soybean already contributes $19 \%$ to deforestation worldwide (Lim, 2018).

Furthermore, biofuels' energy efficiency depends on the feedstock type, cultivation methods, and production conditions. Rapeseed, Europe's main domestic source of biofuels, is a feedstock that is considerably lower in energy per hectare than palm oil. Biofuels in Europe are already heavily subsidised, so they produced way above the opportunity costs of the fossil fuels they replace (Afionis \& Stringer, 2012). To maintain supply, European countries will have to continue to subsidise the production of these more expensive and less energy efficient oilseeds (Erixon \& Abbott, 2009; Meredity, 2012; Wahid, 2008). Afionis \& Stringer (2012) point out that "this confirms the image of a powerful trading state seeking to protect its native biofuels industry, even if doing so entails promoting or subsidising uneconomical, inefficient, and unsustainable production".

The complexity of the biofuel-palm oil hybrid transboundary environmental governance regime lies in different conceptions of sustainability, which stems from different political motivations on both sides. Indeed, leveraging market connections can be a powerful tool for sustainability (Miller et al., 2020), but under certain conditions, market-driven governance can weaken sustainability objectives. Pye (2010) state that despite differences, translational campaign alliances show how civil society from both Southeast Asia and Europe can work together towards positive market outcomes. However, in the three manners, the hybrid state-non-state European biofuels regimes threaten to undo sustainability progress in Southeast Asian producer states. Taking pointers from transnational activism on palm oil and biofuels, the EU should look more towards Southeast Asia for sustainability certification signals. A more open interpretation of sustainability standards, and an understanding that they 
continue to evolve and improve, will support a more holistic and organic approach to sustainability on the ground.

\section{CONCLUSIONS}

While transboundary environmental governance instruments are generally presented as neutral, problem-solving, and consensus-based initiatives (Pichler, 2013), the discussion has illustrated how processes like certification and standards development are, in fact, deeply politicised. Global production systems are integrated economic, political, and discursive systems in which market and political power are intertwined (von Geibler, 2013). Hence, powerful entities in the commodity network use these governance tools to continue to legitimise their power position (Woods, 2003) by exerting 'control at a distance' in disciplining less powerful actors in the network (Klooster, 2005). In this manners, these governance instruments are sites of political contestation where key players' relative political and economic power, and geopolitical position allow powerful ones to broker settlements designed to reinforce unequal power relations (Miller et al., 2020).

Hence, transboundary environmental governance cannot escape from the confines of geopolitical realities (Woods, 2003). These geopolitical tensions complicate the process of transboundary environmental governance, with power asymmetries creating obstacles to coordination, information and knowledge sharing, adaptation to changing circumstances, and resolving trust issues. This is especially the case when different combinations of hybrid regimes clash at various scales of governance (Miller et al., 2020). The deep interrelatedness of the European biofuels regime and the Southeast Asian-based palm oil biofuels regime has given rise to hybrid regulatory features, including overlapping arenas of governance and mutually dependent public-private interactions (Ponte \& Daugbjerg, 2015). The resulting cross-border and cross-scale rulemaking, implementation, and enforcement processes. However, rather than enhancing the overall governance capability to strengthen sustainability objectives, they have weakened them. Key players will leverage upon power dynamics to block or allow access to the benefits of particular resources (in this case, markets) in line with their own interests, with serious environmental implications (Miller et al., 2020).

In conclusion, using the case study of hybrid biofuels and palm oil sustainability governance, the research has attempted to add further weight to the argument that hybrid transboundary governance can weaken sustainability objectives (Stattman et al., 2018), particularly when market incentives are validated without the full understanding of how incentives in particular regimes may have counterproductive spill over effects on other overlapping regimes (Miller et al., 2020). For the EU in particular, its own credibility and power position as a global normative environmental leader is at stake if its trade-related environmental policies are increasingly seen to have detrimental effects outside the EU, in particular on the developmental opportunities of countries in the global South (Afionis \& Stringer, 2012). In this case, hybridity within the biofuels and palm oil sustainability regimes may serve to undo the advances achieved within the highly politicised palm oil sector and discourage further advancements in sustainability. 


\section{REFERENCES}

Afionis, S. \& Stringer, L. C. (2012). European Union leadership in biofuels regulation: Europe as a normative power? Journal of Cleaner Production, 32, 114-123. https://doi.org/10.1016/j.jclepro.2012.03.034

Arief, R. A., Cangara, A. R., Badu, M. N., Baharuddin, A., \& Apriliani, A. (2020). The impact of the European Union (EU) renewable energy directive policy on the management of Indonesian palm oil industry. IOP Conf. Series: Earth and Environmental Science, 575. https://doi.org/10.1088/1755-1315/575/1/012230

Australian Industry Group. (2019). Around the World Australian PMI reports growth in the food and beverages. 10-13.

Badenoch, N. (2001). Mekong regional environmental governance: Perspectives on opportunities and challenges. Perspective, i(October), 3-12.

Bretherton, C. \& Vogler, J. (2000). The European Union as trade actor and environmental activist: Contradictory roles? Journal of Economic Integration, 15(2), 163-194. https://doi.org/10.11130/jei.2000.15.2.163

Choiruzzad, S. A. B. (2019). Save palm oil, save the nation: Palm oil companies and the shaping of Indonesia's national interest. Asian Politics and Policy, 11(1), 8-26. https://doi.org/10.1111/aspp.12431

Delreux, T. (2009). The European Union in international environmental negotiations: An analysis of the Stockholm Convention negotiations. Environmental Policy and Governance, 19(1), 21-31. https://doi.org/10.1002/eet.494

Erixon, F. \& Abbott, R. (2009). Green protectionism in the European Union: How Europe's biofuels policy and the renewable energy directive violate WTO commitments. ECIPE Occasional Paper, No. 1.

European Union - Certain measures concerning palm oil and oil palm crop-based biofuels. (2019). World Trade Organization. https://www.wto.org/english/tratop_e/dispu_e/cases_e/ds593_e.htm

European Union and certain member states - Certain measures concerning palm oil and oil palm crop-based biofuels. (2021). World Trade Organization https://www.wto.org/english/tratop_e/dispu_e/cases_e/ds600_e.htm

Haque, M. S. (2018). Governance for sustainable development in Southeast Asia: Means, concerns, and dilemmas. In A. S. Huque \& H. Zafarullah (Eds.), International Development Governance (pp. 183-204). Boca Raton: Routledge. https://doi.org/10.4324/9781315092577-10 
Indonesia, Malaysia to bolster cooperation in palm oil industry. (2021, October 25). Antara News. $\quad$ https://en.antaranews.com/news/195893/indonesia-malaysia-to-bolstercooperation-in-palm-oil-industry

Kemper, L. \& Partzsch, L. (2018). A water sustainability framework for assessing biofuel certification schemes: Does European hybrid governance ensure sustainability of palm oil from Indonesia? Journal of Cleaner Production, 192, 835-843. https://doi.org/10.1016/j.jclepro.2018.05.053

Klooster, D. (2005). Environmental certification of forests: The evolution of environmental governance in a commodity network. Journal of Rural Studies, 21(4), 403-417. https://doi.org/10.1016/j.jrurstud.2005.08.005

Larsen, R. K., Jiwan, N., Rompas, A., Jenito, J., Osbeck, M., \& Tarigan, A. (2014). Towards 'hybrid accountability' in EU biofuels policy? Community grievances and competing water claims in the Central Kalimantan oil palm sector. Geoforum, 54, 295-305. https://doi.org/10.1016/j.geoforum.2013.09.010

Lélé, S. M. (1991). Sustainable development: A critical review. World Development, 19(6), 607-621. https://doi.org/10.1016/0305-750X(91)90197-P

Lim, S. (2018). EU-Indonesia FTA relations: Palm oil - In for a rough ride? EU-Asia at a Glance. European Institute for Asian Studies, September. http://www.eias.org/wpcontent/uploads/2016/03/Selynn-EU-ASIA-AT-A-GLANCE.pdf

Mazur, G. (2017). EU-ASEAN Free Trade Agreement(s) - Prospects and challenges for interregional FTA. Research Paper of Wroclaw University of Economics, 141-154. https://doi.org/10.15611/pn.2017.486.12

Meredity, M. W. (2012). Malaysia's World Trade Organization challenge to the European Union's renewable energy directive: An economic analysis. Washington International Law Journal, 21(2), 399. https://digitalcommons.law.uw.edu/wilj/vol21/iss2/6

Miller, M. A., Middleton, C., Rigg, J., \& Taylor, D. (2020). Hybrid governance of transboundary commons: Insights from Southeast Asia. Annals of the American Association of $\quad$ Geographers, 297-313. https://doi.org/10.1080/24694452.2019.1624148

Moser, C. \& Leipold, S. (2019). Toward "hardened" accountability? Analysing the European Union's hybrid transnational governance in timber and biofuel supply chains. Regulation and Governance, May, 1-18. https://doi.org/10.1111/rego.12268

Nesadurai, H. E. S. (2018). New constellations of social power: States and transnational private governance of palm oil sustainability in Southeast Asia. Journal of Contemporary Asia, 48(2), 204-229. https://doi.org/10.1080/00472336.2017.1390145

Oosterveer, P. (2020). Sustainability of palm oil and its acceptance in the EU. Journal of Oil Palm Research, 32, 365-376. https://doi.org/10.21894/jopr.2020.0039 
Pacheco, P., Schoneveld, G., Dermawan, A., Komarudin, H., \& Djama, M. (2020). Governing sustainable palm oil supply: Disconnects, complementarities, and antagonisms between state regulations and private standards. Regulation and Governance, 14(3), 568-598. https://doi.org/10.1111/rego.12220

Panels established to review Indian tech tariffs, Japanese export restrictions, EU palm oil measures. (2020, July 29). World Trade Organization. https://www.wto.org/english/news e/news20_e/dsb_29jul20 e.htm

Pichler, M. (2013). "People, Planet \& Profit": Consumer-oriented hegemony and power relations in palm oil and agrofuel certification. Journal of Environment and Development, 22(4), 370-390. https://doi.org/10.1177/1070496513502967

Ponte, S. \& Daugbjerg, C. (2015). Biofuel sustainability and the formation of transnational hybrid governance. Environmental Politics, 24(1), 96-114. https://doi.org/10.1080/09644016.2014.954776

Pye, O. (2010). The biofuel connection - transnational activism and the palm oil boom. Journal of Peasant Studies, 37(4), 851-874. https://doi.org/10.1080/03066150.2010.512461

Rifin, A., Feryanto, Herawati, \& Harianto. (2020). Assessing the impact of limiting Indonesian palm oil exports to the European Union. Journal of Economic Structures, 9(1). https://doi.org/10.1186/s40008-020-00202-8

Roozen, N. (2021, February 10). Changing the palm oil narrative: The EU seems willing to turn the page. Solidaridad. https://www.solidaridadnetwork.org/news/changing-thepalm-oil-narrative-eu-seems-willing-to-turn-the-page/

RSPO-RED scheme not to be renewed. (2020, March 25). Roundtable on Sustainable Palm Oil. https://www.rspo.org/news-and-events/announcements/rspored-scheme-not-tobe-renewed

Sani, R. K. M. (2020, January 29). PALM OIL: MSPO certification gains international recognition. Bernama (Facebook post). https://m.facebook.com/188457585554/photos/a.10150341276330555/101581344912 $25555 /$ type $=3 \&$ source $=57 \&$ refid $=52 \&$ tn $=$ EH-R

Siahaan, T. K. (2020). Indonesia environmental diplomacy in President Joko Widodo's era (2014-2019) of the issue rejection Indonesia's CPO by European Union. Sociae Polites, 21(1), 74-95. https://doi.org/10.33541/sp.v21i1.1960

Sharman, A. \& Holmes, J. (2010). Evidence-based policy or policy-based evidence gathering? Biofuels, the EU and the 10\% target. Environmental Policy and Governance, 20(5), 309-321. https://doi.org/10.1002/eet.543

Stattman, S. L., Gupta, A., Partzsch, L., \& Oosterveer, P. (2018). Toward sustainable biofuels in the European Union? Lessons from a decade of hybrid biofuel governance. Sustainability (Switzerland), 10(11), 1-17. https://doi.org/10.3390/su10114111 
Thacher, P. S. (1977). The Mediterranean action plan. Ambio, 6(6), 308-312. http://www.jstor.org/stable/4312310

Tham, S. Y. (2012). Negotiating for a Malaysia-EU FTA contesting interests from Malaysia's perspective. Ifri Center for Asian Studies.

Varkkey, H. (2016). The Haze Problem in Southeast Asia: Palm Oil and Patronage. Oxon: Routledge.

Varkkey, H. (2018, February). EU's anti-palm oil measures do not help the environment. In S. M. Tang (Ed.), ASEAN Focus (pp. 8-9). ISEAS Yusof Ishak Institute.

Varkkey, H. (2020, April 02). Palm oil politics still threaten EU-Malaysia ties. East Asia Forum. https://www.eastasiaforum.org/2020/04/02/palm-oil-politics-still-threaten-eumalaysia-ties/

Vogler, J. \& Stephan, H. R. (2007). The European Union in global environmental governance: Leadership in the making? International Environmental Agreements: Politics, Law and Economics, 7(4), 389-413. https://doi.org/10.1007/s10784-007-9051-5

von Geibler, J. (2013). Market-based governance for sustainability in supply chains: Conditions for successful standard setting in the palm oil sector. Journal of Cleaner Production, 56, 39-53. http://dx.doi.org/10.1016/j.jclepro.2012.08.027

Wahid, M. B. (2008). EU's Renewable Energy Directive : Possible Implications on Malaysian Palm Oil Trade. Oil Palm Industry Economic Journal, 6(2), 1-7.

Wibowo, R. \& Ratnawati. (2020). Conflict dynamics of protectionism policy trading of biofuel commodities between Indonesia and the European Union. LPPM UPN "Veteran" Yogyakarta Conference Series; Proceeding on Political and Social Science, 1(1), 230237. https://doi.org/10.31098/pss.v1i1.200

Woods, K. (2003). Transboundary environmental governance in the Mekong River basin: Civil society spaces for transboundary participation. Presented at Politics of the Commons: Articulating Development and Strengthening Local Practices, Chiang Mai, 11-14 July. 